\title{
Spatiotemporal Variations of Aerosol Optical Depth in the Atmosphere over Baikal Region Based on MODIS Data
}

\author{
Mikhail Taschilin ${ }^{1, *(\mathbb{D})}$, Irina Yakovleva ${ }^{1}$, Sergey Sakerin ${ }^{2}{ }^{\oplus}$, Olga Zorkaltseva $^{1}\left(\mathbb{D}\right.$, Andrey Tatarnikov $^{1}$ \\ and Ekaterina Scheglova ${ }^{1}$ \\ 1 Institute of Solar-Terrestrial Physics of the Siberian Branch of the RAS, 664033 Irkutsk, Russia; \\ resels@iszf.irk.ru (I.Y.); meteorologist-ka@yandex.ru (O.Z.); andrey@iszf.irk.ru (A.T.); \\ katscheg@iszf.irk.ru (E.S.) \\ 2 V.E. Zuev Institute of Atmospheric Optics of Siberian Branch of the Russian Academy of Sciences, 634055 \\ Tomsk, Russia; sms@iao.ru \\ * Correspondence: miketash@iszf.irk.ru; Tel.: +89-148-704-943
}

Citation: Taschilin, M.; Yakovleva, I.;

Sakerin, S.; Zorkaltseva, O.;

Tatarnikov, A.; Scheglova, E.

Spatiotemporal Variations of Aerosol Optical Depth in the Atmosphere over Baikal Region Based on MODIS Data. Atmosphere 2021, 12, 1706. https://doi.org/10.3390/atmos12121706

Academic Editor: Klaus Schäfer

Received: 15 November 2021 Accepted: 16 December 2021 Published: 20 December 2021

Publisher's Note: MDPI stays neutral with regard to jurisdictional claims in published maps and institutional affiliations.

Copyright: (c) 2021 by the authors. Licensee MDPI, Basel, Switzerland. This article is an open access article distributed under the terms and conditions of the Creative Commons Attribution (CC BY) license (https:/ / creativecommons.org/licenses/by/ $4.0 /)$.

\begin{abstract}
This paper considers spatiotemporal distribution and seasonal variability of aerosol optical depth (AOD) of the atmosphere at the $0.55 \mu \mathrm{m}$ wavelength in the atmosphere over the Baikal region of Russia based on long-term data (2005-2019) from satellite observations (MODIS/AQUA). A comparison of satellite AOD values with the AERONET record at the Geophysical Observatory of Institute of Solar-Terrestrial Physics of Siberian Brunch of Russian Academy of Science was performed. The results show that interannual AOD variability is mainly due to forest fires. The highest atmospheric transparency was in 2010, 2013 and 2016, and the lowest was in 2008, 2012 and 2014. It is noted that $\mathrm{AOD}$ decreased with latitude with a gradient $\triangle \mathrm{AOD}=0.002 \div 0.001$ per degree of latitude. The mean seasonal variations in AOD at the six satellite overpass points were characterized by spring (April) and summer (July) highs and low AOD values in autumn. From June to November, the drop in AOD monthly means was more than $60 \%$.
\end{abstract}

Keywords: aerosol optical depth (AOD); remote sensing; photometry; Baikal; AERONET; MODIS

\section{Introduction}

Long-standing research into variations in atmospheric radiatively significant components is a challenge in the context of the Earth's climate change. Along with greenhouse gases and cloudiness, atmospheric aerosols play an essential role in radiation processes. The main and most studied optical characteristic of aerosols is the aerosol optical depth (AOD) of the atmosphere. Many authors [1-7] have analyzed the interannual variations and seasonal variability of different parameters of the atmospheric transparency over Russia. In [4], the results of long-term studies (1995-2017) of the physical properties and chemical composition of atmospheric aerosols in the Baikal region in three sites are considered. The paper concludes that forest fires near Baikal cause an increase in the concentrations of $\mathrm{Na}+$, $\mathrm{K}+, \mathrm{NH} 4+, \mathrm{Cl}-$, and NO3- ions in Baikal region aerosols. The research was carried out at three sites: Irkutsk, Listvyanka, and Mondy; only one site (Listvyanka) was located directly in the territory of Lake Baikal.

Currently, the global Aerosol Robotic Network (AERONET) provides the most complete information on the variability of spectral atmospheric AOD, but there is only one station operating in the Baikal region. In addition, atmospheric AOD is reconstructed from solar radiation measurements in the network of actinometric stations, but only at the wavelength of $0.55 \mu \mathrm{m}$ [8]. In the Baikal region, these stations are located in Babushkin town, Ivolginsk village, and Khuzhir settlement.

Recently, to analyze spatial and temporal variations in atmospheric AOD, researchers have increasingly begun to use satellite measurements, in particular, by Moderate Resolution Imaging Spectroradiometer (MODIS) Terra/Aqua satellites. The achieved level 
of AOD reconstruction error is thought to be acceptable for analyzing its spatiotemporal variability [9]. Researchers often study AOD variations using the MODIS radiometer data [5,10-13]. In [5], the AOD over the Baikal region was retrieved for 2000-2010 using the MODIS data with a resolution of $10 \mathrm{~km}$ per pixel and the V5.2 retrieval algorithm developed by NASA. The AOD characteristics of spatial and temporal variation over the Baikal region were analyzed: the mean AODs in spring and summer were higher, with the highest value of 0.26 in May; the mean AODs in autumn and winter were lower and steady. These results were in qualitative agreement with the results of our work [7] studying the AOD in the Tunka valley.

This paper discusses interannual and seasonal variations in atmospheric AOD over the Baikal region of Russia based on MODIS data at a resolution of $3 \mathrm{~km}$ per pixel and the V6.1 retrieval algorithm developed by NASA. The analysis was carried out in 2005-2019 for eight months, from April to November. We did not include the winter months in the analysis due to insufficient data and the significant error in AOD detection above the snow surface [9]. To evaluate the validity of MODIS data, we compared them with ground-based AERONET AOD measurements by the CIMEL CE-318 photometer at the Geophysical Observatory of the Institute of Solar-Terrestrial Physics of Siberian Brunch of Russian Academy of Science (ISTP SB RAS) near Tory settlement.

\section{Research Region and Data}

\subsection{Study Area}

Lake Baikal is the world's largest freshwater lake by volume, containing $22-23 \%$ of the world's fresh surface water. The peculiarities of the climatic conditions of the Lake Baikal basin are determined by its location in the central part of the Asian continent, radiation and circulation processes, and the originality of the landscapes of this region. The huge water mass of the lake has a significant impact on the climate. The average January temperature is up to $-18{ }^{\circ} \mathrm{C}$ and below, in July and August from $+11^{\circ} \mathrm{C}$ to $+14.1^{\circ} \mathrm{C}$. The average annual temperature is $+1.9^{\circ} \mathrm{C}$. Precipitation is up to $370 \mathrm{~mm}$ on the coast and $400-500 \mathrm{~mm}$ in the mountains. At the same time, the climatic conditions of the lake basin in the Baikal region are extremely heterogeneous.

The analysis was performed over six satellite overpasses points: settl. (settlement) Tory $\left(51.78^{\circ} \mathrm{N}, 103^{\circ} \mathrm{E}\right.$, el. (elevation) $\left.670 \mathrm{~m}\right)$, settl. Bolshiye Koty $\left(51.91^{\circ} \mathrm{N}, 105.06^{\circ} \mathrm{E}\right.$, el. $470 \mathrm{~m})$, town Babushkin $\left(51.83^{\circ} \mathrm{N}, 106.06^{\circ} \mathrm{E}\right.$, el. $\left.470 \mathrm{~m}\right)$, settl. Uzury $\left(53.31^{\circ} \mathrm{N}, 107.73^{\circ} \mathrm{E}\right.$, el. $465 \mathrm{~m})$, settl. Sarma $\left(53.08^{\circ} \mathrm{N}, 106.83^{\circ} \mathrm{E}\right.$, el. $\left.465 \mathrm{~m}\right)$, and village Maximikha $\left(53.25^{\circ} \mathrm{N}\right.$, $108.73^{\circ}$ E, el. $460 \mathrm{~m}$ ). Selected points are shown in Figure 1. We selected these points based on our previous ground based expeditionary actinometer equipment measurements of aerosol characteristics in 2017-2019. These expeditionary measurements were carried out at observatories and remote stations of the ISTP SB RAS. The retrieval of satellite data over these locations used the $0.1 \times 0.1$ degree spatial window. 


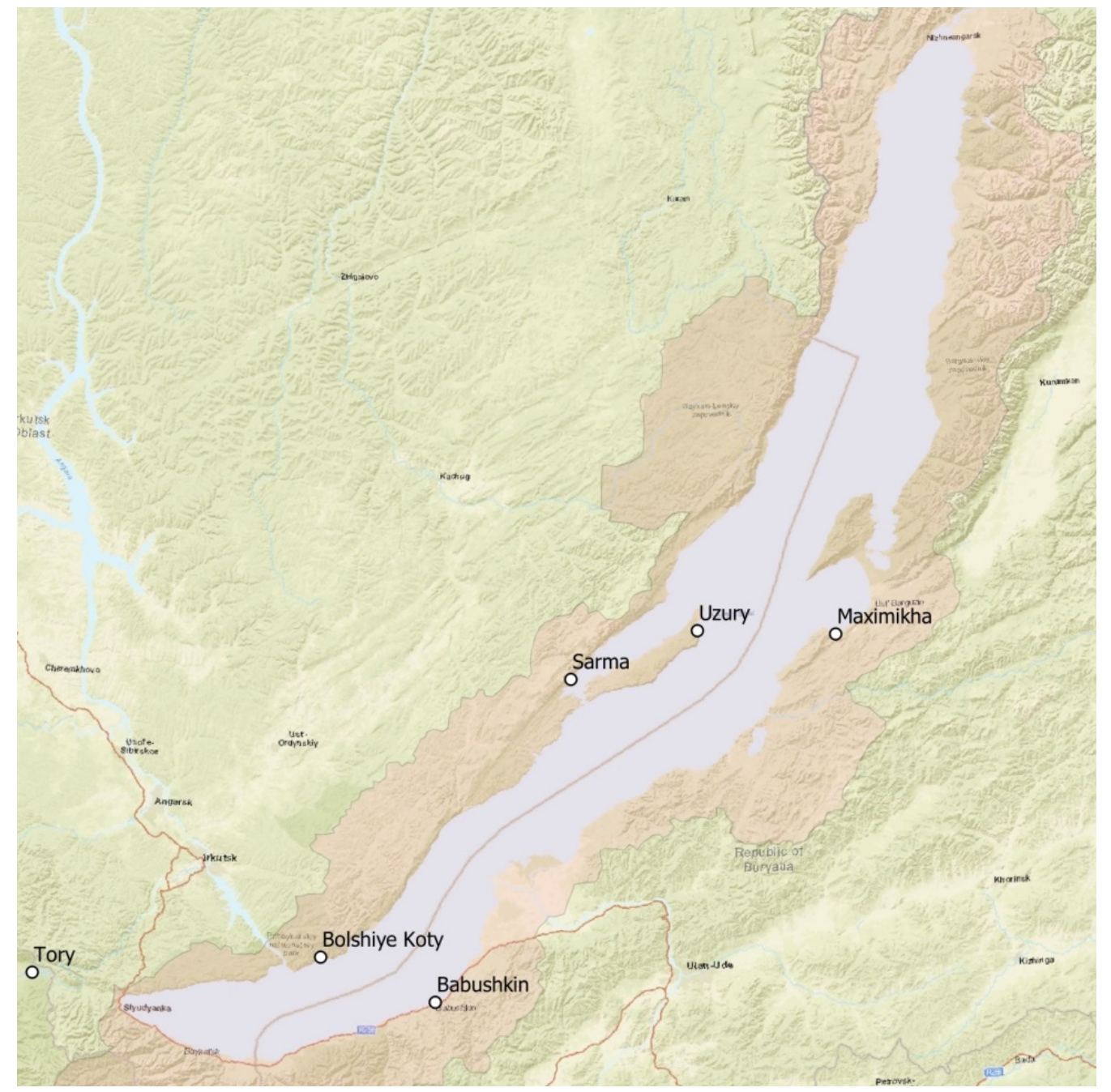

Figure 1. Satellite overpass points for MODIS data.

\subsection{Data}

The analysis of AOD spatiotemporal variations in the atmosphere over the Baikal region employed data from MODIS/Aqua, with a $3 \mathrm{~km}$ per pixel spatial resolution, MYD04_3K product, collection 6.1 (https:/ / ladsweb.modaps.eosdis.nasa.gov/archive/ allData/61/MYD04_3K, accessed date 14 November 2021) for 2005-2019 at $0.55 \mu \mathrm{m}-\mathrm{AOD}$ (550 nm).

Figure 2 presents the spatial distribution of the AOD $(550 \mathrm{~nm})$ annual means from MODIS measurements for 2005-2019. Abnormally high/low AOD values to the northwest of settl. Tory $\left(101-103^{\circ} \mathrm{E}, 51.5-52.5^{\circ} \mathrm{N}\right)$ are most likely related to the orographic features of the territory (the Eastern Sayan mountain system) with high albedo of the underlying surface. High snow albedo leads to bias in AOD detection above the snow surface [9]. An analysis of Figure 2 will be presented in the Discussion section. 


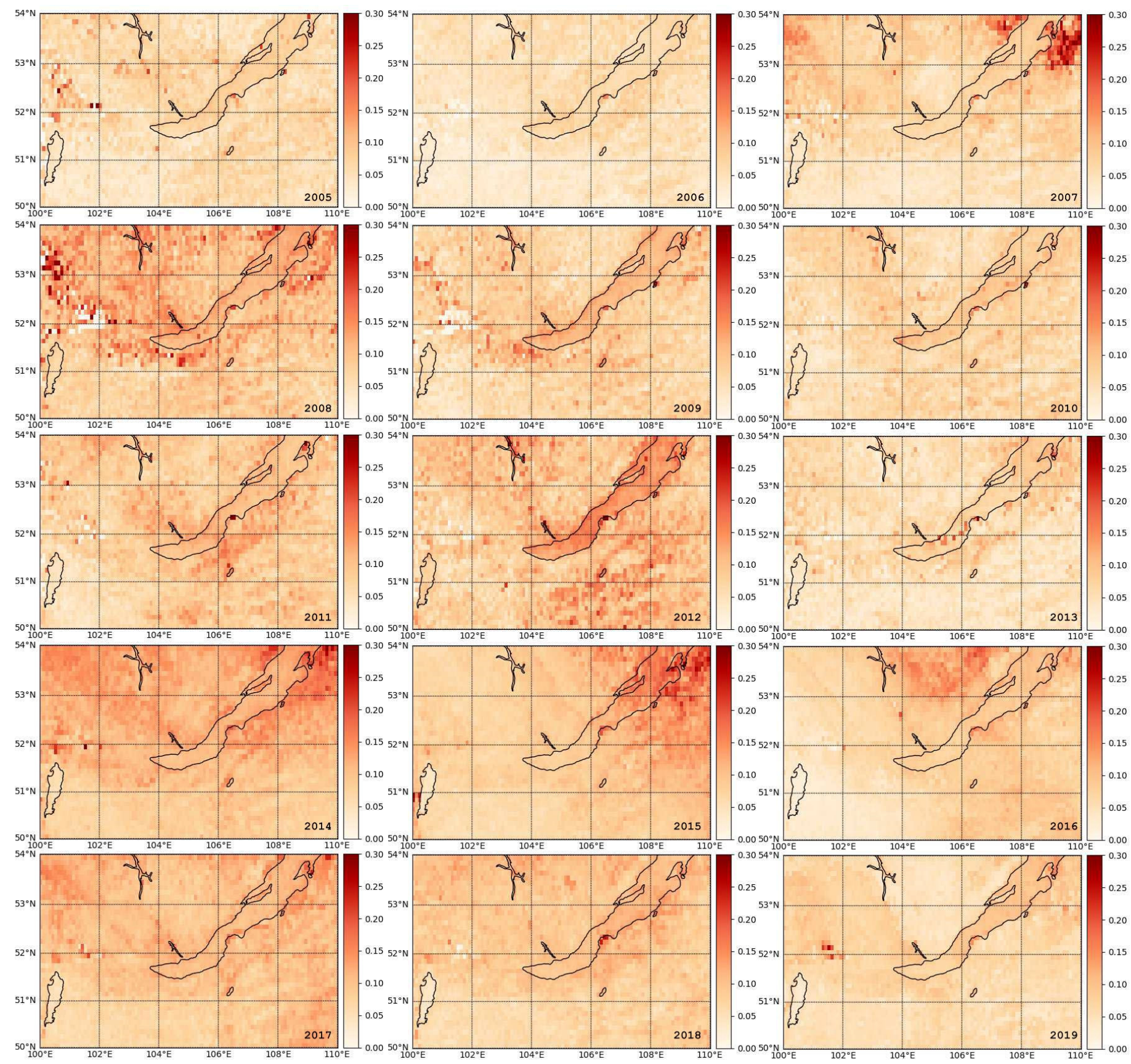

Figure 2. Spatial distribution of AOD $(550 \mathrm{~nm})$ annual means from MODIS data for 2005-2019.

\section{Results}

\subsection{Validation}

We compared MODIS data to the ground-based observations of AOD (550 nm) with sun photometer CIMEL CE-318 (level 2.0), a part of the global AERONET, at the Geophysical Observatory of the Institute of Solar-Terrestrial Physics Siberian Branch of the Russian Academy of Science (settl. Tory). We compared long-term AOD monthly means at $0.55 \mu \mathrm{m}$. Since there are no monthly average AERONET data in some years for the autumn or spring months, when the photometer is being calibrated, a total of 86 joint measurements were obtained for a 15-year period. Because CIMEL CE-318 does not have the $0.55 \mu \mathrm{m}$ spectral channel, we took the interpolated AOD (550 nm) values to compare them with the MODIS record. These values were calculated by the formula:

$$
\operatorname{AOD}(550 \mathrm{~nm})=\operatorname{AOD}(500 \mathrm{~nm}) \times(0.55 / 0.50)^{-\alpha \times(440-675)}
$$


Figure 3 presents a graph of the comparison of long-term AOD $(550 \mathrm{~nm})$ monthly means from satellite (MODIS) and ground-based measurements (CIMEL CE-318, AERONET) at the Geophysical Observatory of ISTP SB RAS, 2005-2019. The comparison of the two types of data showed a good agreement for atmospheric AOD: a correlation coefficient of 0.86 and a standard deviation of 0.05 , a $p$-value is 0.03078 , when the result is significant at $p<0.05$.

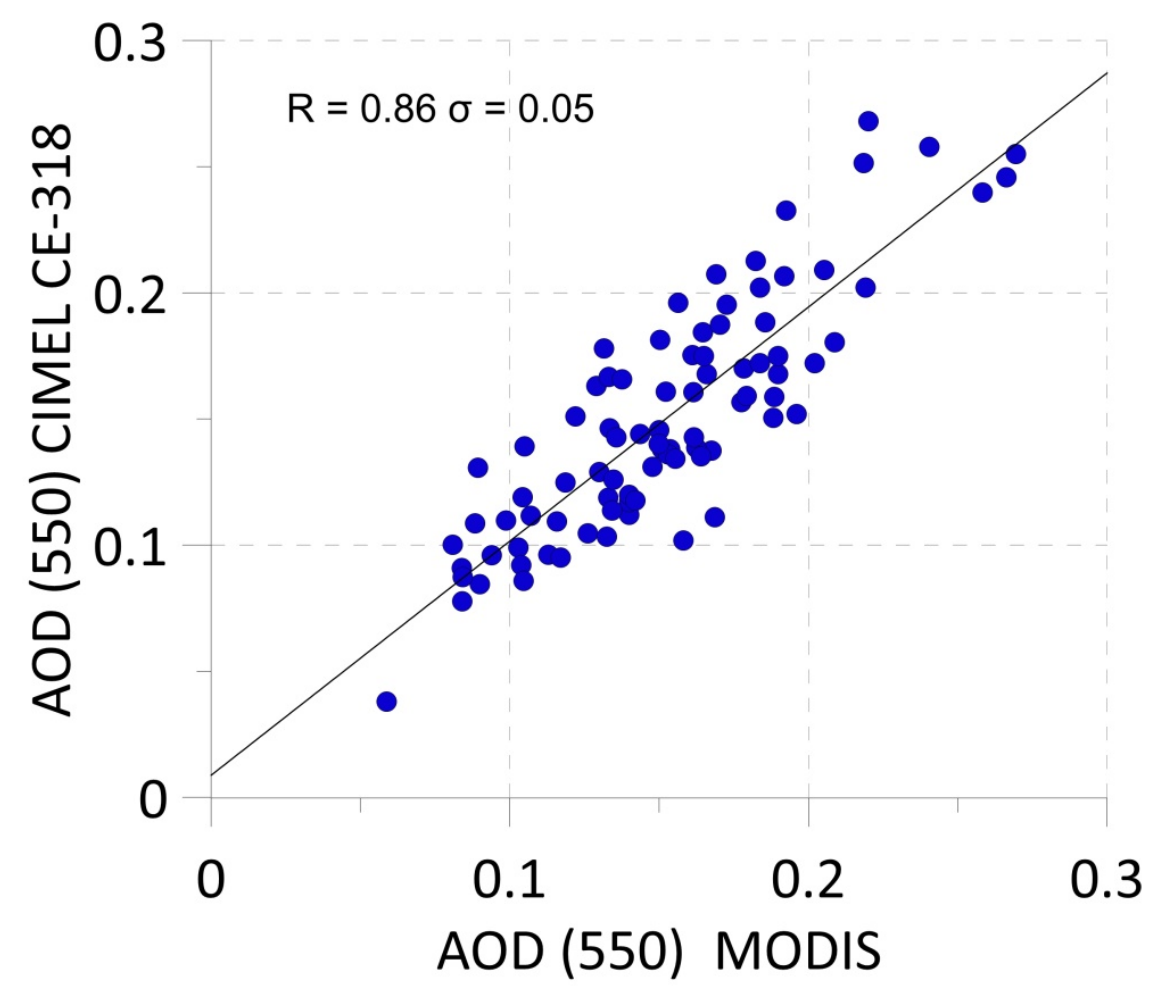

Figure 3. Comparison of AOD $(550 \mathrm{~nm})$ monthly means from satellite (MODIS) and ground-based (CIMEL CE-318) measurements at the Geophysical Observatory of ISTP SB RAS, 2005-2019.

\subsection{Interannual Variations in Atmospheric $A O D$}

Currently, major explosive volcanic eruptions are thought to be the main factor influencing long-term AOD variability [14].

The next most crucial factor is massive forest fires [15-18] in the boreal zone (including the Baikal region), which have become more frequent in recent years because of anthropogenic factors. Figure 4 shows the AOD $(550 \mathrm{~nm})$ annual means for six observation points in 2005-2019. The figure shows the similar patterns of changes in atmospheric transparency in all regions: AOD highs in 2008, 2012 and 2014 and lows in 2013 and 2016, with the absolute minimum in 2010. 


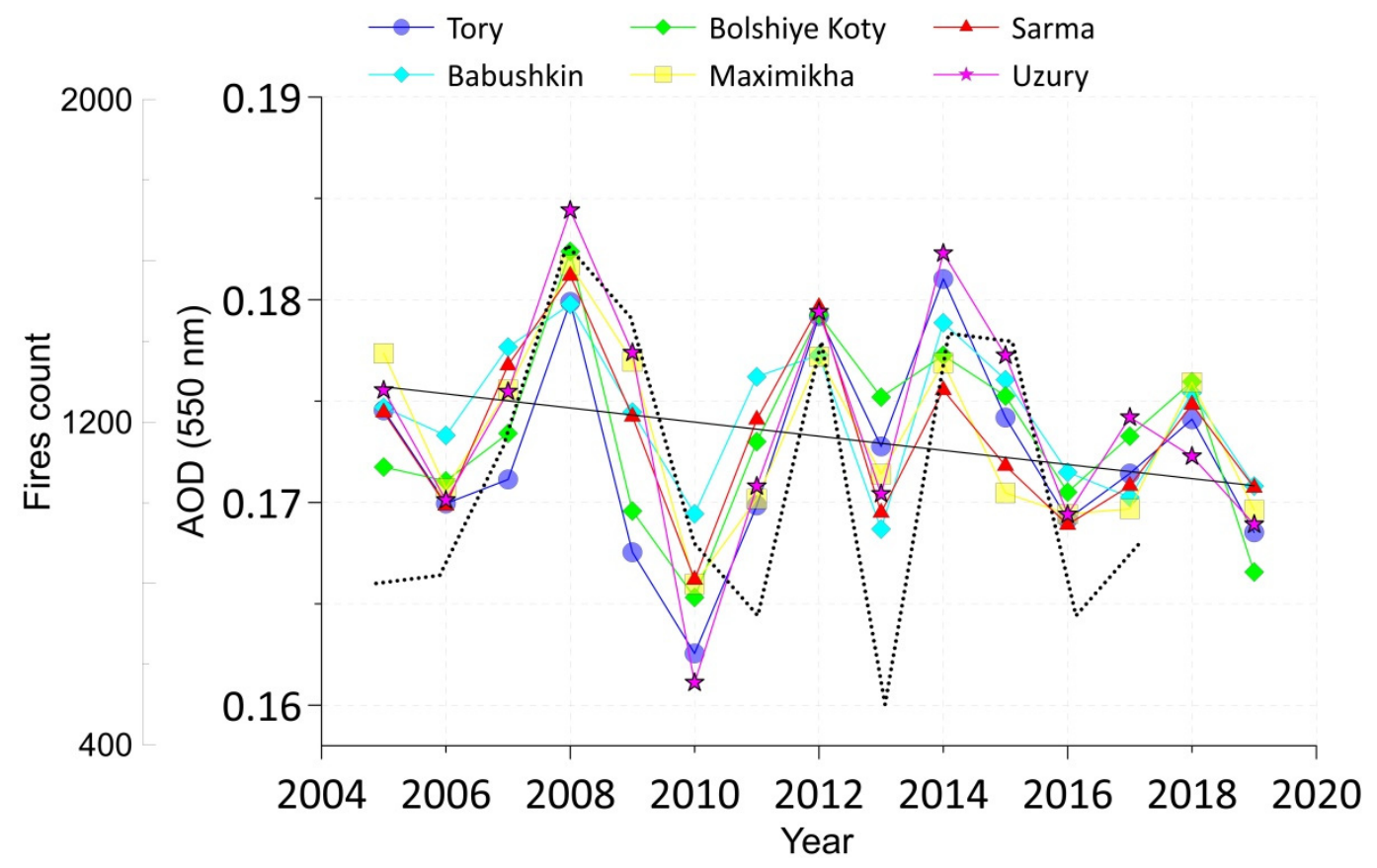

Figure 4. AOD (550 nm) interannual variability for six observation points in 2005-2019. Straight line shows the linear trend; dotted line depicts fire count per year for Baikal region.

Table 1 shows long-term AOD means according to MODIS data, calculated from monthly means over 2005-2019. The long-term AOD mean for the Baikal region (0.17) is close in value to the global annual mean of AOD (0.16) from satellite data (MODIS, TOMS, AVHRR) [19].

Table 1. AOD long-term means for 2005-2019 based on MODIS data.

\begin{tabular}{cccccc}
\hline Data & Tory & Babushkin & Bolshiye Koty & Maximikha & Sarma \\
\hline Maximum & 0.181 & 0.180 & 0.182 & 0.182 & 0.181 \\
\hline Minimum & 0.163 & 0.169 & 0.165 & 0.166 & 0.166 \\
\hline Mean & 0.172 & 0.174 & 0.173 & 0.173 & 0.173 \\
\hline
\end{tabular}

For the 15-year period addressed, there is a gradual decrease in atmospheric turbidity. In Figure 4, the straight line depicts the linear negative trend for AOD (550 nm) with an overall decreasing trend of 0.034 and a mean of 0.173 (linear trend equation $y=-0.00035 x+0.87428$ year $^{-1}, R^{2}=0.129$ ). A similar trend is obtained in [8], which associates the atmosphere cleansing from aerosols with the absence of major volcanic eruptions and lower anthropogenic (industrial) emissions.

We assessed the relationship between the variations in long-term AOD $(550 \mathrm{~nm})$ means at the satellite overpass points.

Table 2 shows that there is a fairly high correlation of atmospheric AOD in the studied region. This is indicative of the common processes of AOD variability in the Baikal region. The maximum correlations of 0.905 and 0.9 were observed in Tory vs Bolshiye Koty, Maximikha vs Sarma, respectively. The correlation decreased with distance between the points. The satellite overpass points Tory and Bolshiye Koty, Maximikha and Sarma are located at roughly the same latitudes, respectively. In [20], the authors note that AOD values decreased with latitude, while these changes were minor in longitude. Table 1 suggests that $\mathrm{AOD}$ values decrease from south to north with an approximate average gradient of $\triangle \mathrm{AOD}=0.002 \div 0.001$ per degree of latitude. This is consistent with the results in [20], where the latitudinal decrease in AOD $(550 \mathrm{~nm})$ varied from 0.002 in January to 0.004 in July. 
Table 2. Cross-correlation coefficients of AOD variations over satellite overpass points.

\begin{tabular}{cccccc}
\hline Observation Point & Tory & Babushkin & Bolshiye Koty & Maximikha & Sarma \\
\hline Tory & 1 & 0.701 & 0.905 & 0.738 & 0.755 \\
\hline Babushkin & & 1 & 0.687 & 0.765 & 0.874 \\
\hline Bolshiye Koty & & & 1 & 0.702 & 0.774 \\
\hline Maximikha & & & 1 & 0.9 \\
\hline Sarma & & & & 1 \\
\hline
\end{tabular}

\subsection{Seasonal Variations in AOD Monthly Means}

Figure 5 shows the mean long-term annual variations in AOD $(550 \mathrm{~nm})$ for 2005-2019.

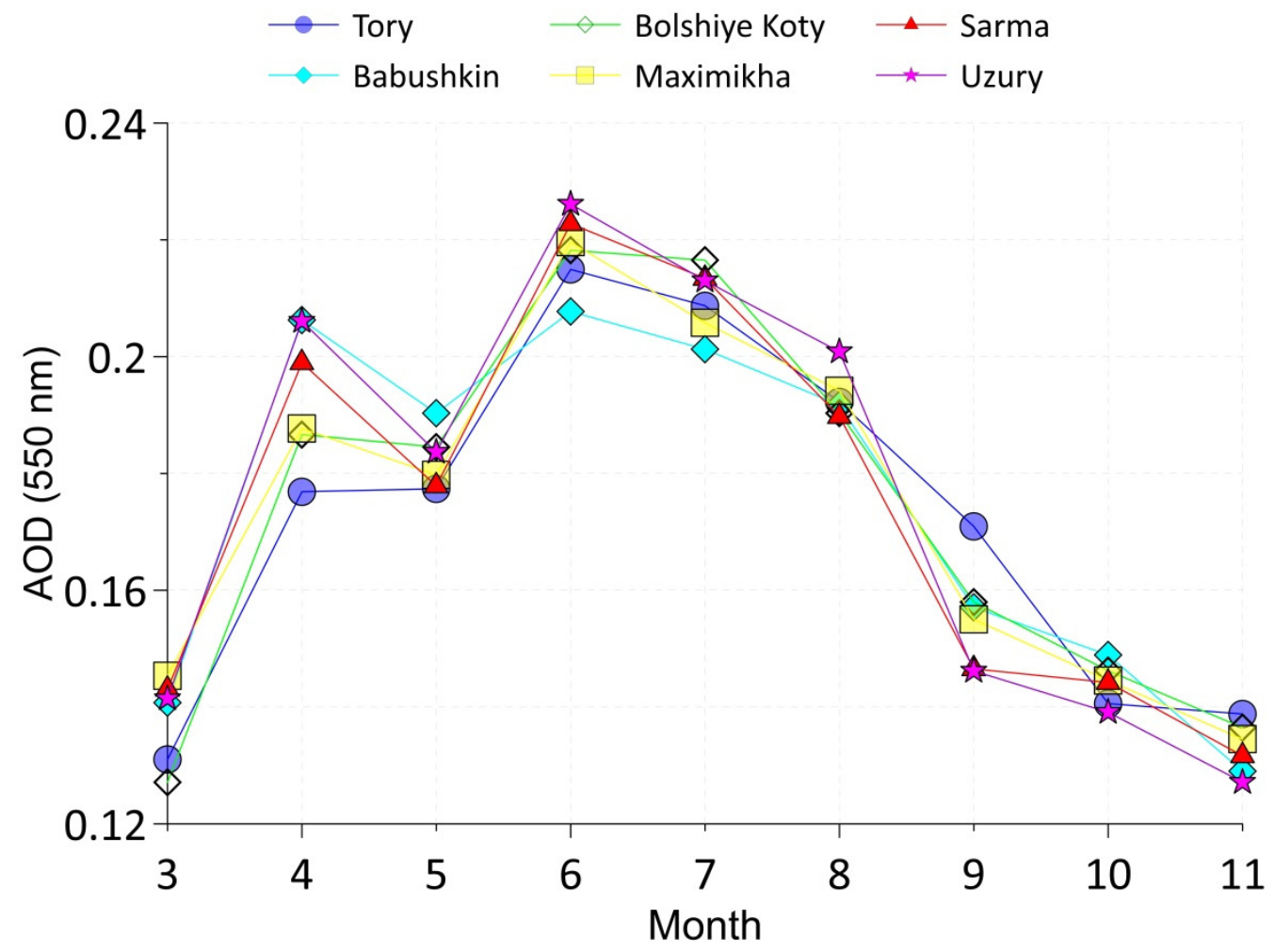

Figure 5. The mean long-term annual variation in AOD for six satellite overpass points for 2005-2019 according to MODIS record (March-November).

We did not include the winter months in the analysis due to the high albedo of the underlying surface [9]. The pattern of AOD annual variations from MODIS was qualitatively consistent with the results of previous ground-based measurements at the Geophysical Observatory of ISTP SB RAS [7]. The common pattern of intra-annual AOD variability over satellite overpass points was the first high in April, the local low in May, the second high in June, and the low in September-November. On average, the relative change in AOD $(550 \mathrm{~nm}$ ) from June to November was more than $60 \%$, which is consistent with the results in [8], where the increase in AOD during the spring/summer period reached $60-80 \%$, compared to the lowest values in autumn and winter.

\section{Discussion}

We compared MODIS data to the ground-based observations of AOD $(550 \mathrm{~nm})$ with the sun photometer CIMEL CE-318 (level 2.0), a part of the global AERONET, at the Geophysical Observatory of ISTP SB RAS (settl. Tory). The comparison of the two types of data showed good agreement for atmospheric AOD (see Figure 3): a correlation coefficient 
of 0.86 , a standard deviation of 0.05 , and $p$-value is 0.03078 , with the result significant at $p<0.05$. Based on the comparison, we concluded that the satellite data were consistent with the stated level of accuracy [9], a correlation coefficient of 0.64 and a standard deviation of 0.06. We also found that the use of the long-term AOD monthly means was feasible for the assessment of atmospheric spatiotemporal variations within the Baikal region. The similar patterns in the changes in atmospheric turbidity in all regions (AOD highs in 2008, 2012 and 2014 and lows in 2013 and 2016, with the absolute minimum in 2010; see Figure 4) are qualitatively consistent with the earlier paper [7] examining AOD interannual variations at the $0.5 \mu \mathrm{m}$ wavelength based on data from the CIMEL CE-318 photometer at the Geophysical Observatory of ISTP SB RAS.

The AOD highs in 2008, 2012 and 2014 are clearly shown in Figure 2. As can be seen from Figure 2, mesoscale inhomogeneities are observed in the mean annual spatial distributions of AOD. These inhomogeneities, in the general case, do not have a regular spatial distribution and, apparently, depend on the transfer of smoke aerosol arising as a result of forest fires. In [21], the authors analyzed parameters of forest fires in the Baikal region using VEGA PRO remote sensing data for 2002-2017. One of the results from this analysis is shown as a dotted line in Figure 4 as the count of forest fires per year. As we can see from the Figure 4, the peaks in the fires count in 2008, 2012 and 2014 coincide with the periods of maximum atmospheric AOD, confirming the defining influence of forest fires (number and intensity) on the formation of interannual AOD variability during the period studied. In work [4], it is shown that components of soil erosion origin ( $\mathrm{Al}, \mathrm{Fe}, \mathrm{Zn}$, $\mathrm{Cr}, \mathrm{Ba}$ ) dominate in the elemental composition of the aerosols in the Baikal region. Their concentration increased during forest fires up to 1.4-6 times on average. This is consistent with the results presented in Figures 2 and 4.

Therefore, the spring and summer maximums and minimums of AOD variability in the Baikal region were analyzed (see Figure 5). The April maximum may be due to the intensification of photochemical processes of secondary (fine) aerosol formation, the release of aerosol material during snowmelt, higher emission of coarse aerosols from exposed soil, and smoke aerosols. According to [22], the first fires in the Baikal region occur in April, which has the lowest relative air humidity, associated with the lowest atmospheric precipitation and a sharp increase in air temperature. The local AOD minimum in May can be related to the development of fresh plant cover, and higher precipitation that flushes out the aerosols, reduces the likelihood of forest fires, and leads to lower atmospheric turbidity. The combination of high temperature and low relative air humidity in June causes hot dry winds and droughts contributing to fire hazards and hence, greater AOD in June. During the other half of summer (July-August), cyclonic activity intensifies dramatically, resulting in higher relative humidity and rainfall [23]. Thus, the Baikal region belongs to a group of regions that display seasonal variations in atmospheric transparency, with the minimum in spring and summer and the maximum in autumn.

\section{Conclusions}

The comparison of MODIS satellite data to ground-based measurements from the CIMEL CE-318 sun photometer showed good agreement for atmospheric AOD: 0.86 correlation coefficient and 0.05 standard deviation. We have concluded upon the consistency of satellite data with the stated error level [9] and the feasibility of using long-term AOD monthly means to assess spatiotemporal variations in atmospheric AOD.

The analysis of atmospheric spatiotemporal variations in the Baikal region revealed the following features. The interannual variability of AOD is basically due to the impact of forest fires. It is the same in all regions: the highest atmospheric AOD was in 2008, 2012 and 2014, and the lowest was in 2010, 2013 and 2016. For the Baikal region, the long-term mean of AOD (0.17) was close to the global annual mean of AOD (0.16) obtained from satellite data (MODIS, TOMS, AVHRR) [6]. For the 15-year period under review, there was a gradual decrease in atmospheric AOD: a linear negative trend for AOD ( $550 \mathrm{~nm})$ was 
revealed with an overall decreasing trend by 0.034 with a mean of 0.173 . It is noted that AOD decreases with latitude with a gradient $\triangle \mathrm{AOD}=0.002 \div 0.001$ per degree of latitude.

The mean seasonal variations in AOD by MODIS data over six sites were characterized by spring (April) and summer (July) highs and low AOD values in autumn. From June to November, the decrease in AOD $(550 \mathrm{~nm})$ monthly means was more than $60 \%$.

Author Contributions: Conceptualization, M.T.; methodology, M.T.; software, I.Y. and A.T.; validation, O.Z.; formal analysis, S.S.; investigation, M.T., O.Z. and S.S.; resources, E.S.; data curation, M.T.; writing—original draft preparation, O.Z.; writing—review and editing, M.T.; visualization, E.S.; supervision, M.T.; project administration, M.T.; funding acquisition, M.T. All authors have read and agreed to the published version of the manuscript.

Funding: The research was financially supported by the Major Project of the Ministry of Science of Higher Education "Fundamental Principles, Methods and Technologies of Digital Monitoring and Predicting the Environmental Situation of the Baikal Natural Area" (grant No. 075-15-2020-787).

Data Availability Statement: Data are available on request due to the large amount and computational nature.

Acknowledgments: The MODIS AOD data was obtained from the NASA Langley Research Centre Atmospheric Science Data Center. The efforts of PIs of various AERONET sites used in this study are highly appreciated. This is a translation of "Spatio-temporal variations of the aerosol optical depth in the Baikal region" originally published in Russian by journal "Sovremennye problemy distantsionnogo zondirovaniya Zemli iz kosmosa" (Sovr. Probl. DZZ Kosm.), translated as "Current problems in remote sensing of the Earth from space" 2021, V.18, Num. 1, pp. 219-226. Permission was granted by journal "Sovremennye problemy distantsionnogo zondirovaniya Zemli iz kosmosa".

Conflicts of Interest: The authors declare no conflict of interest. The funders had no role in the design of the study; in the collection, analyses, or interpretation of data; in the writing of the manuscript, or in the decision to publish the results.

\section{References}

1. Zhdanova, E.Y.; Chubarova, N.Y.; Lyapustin, A.I. Assessment of urban aerosol pollution over the Moscow megacity by the MAIAC aerosol product. Atmos. Meas. Tech. 2020, 13, 877-891. [CrossRef]

2. Paznukhov, A.; Soina, A.; Milinevsky, G.; Yampolsky, Y. Weekly cycle in the atmosphere aerosol variations for industrial regions. Adv. Astron. Space Phys. 2019, 9, 20-27. [CrossRef]

3. Rakitin, V.S.; Elansky, N.F.; Wang, P.; Wang, G.; Pankratova, N.V.; Shtabkin, Y.A.; Skorokhod, A.I.; Safronov, A.N.; Makarova, M.V.; Grechko, E.I. Changes in trends of atmospheric composition over urban and background regions of Eurasia: Estimates based on spectroscopic observations. Geogr. Environ. Sustain. 2018, 11, 84-96. [CrossRef]

4. Golobokova, L.P.; Khodzher, T.V.; Obolkin, V.A.; Potemkin, V.L.; Khuriganova, O.I.; Onischuk, N.A. Aerosol in the atmosphere of the Baikal region: History and contemporary researches. Limnol. Freshw. Biol. 2018, 1, 49-57. [CrossRef]

5. Wei, P.; Hong, J.; Yong, Z. Using MODIS to retrieve the AOT over the region of Baikal. In IOP Conference Series: Earth and Environmental Science; IOP Publishing: Bristol, UK, 2014; Volume 17, p. 012038. [CrossRef]

6. Chubarova, N.Y.; Poliukhov, A.A.; Gorlova, I.D. Long-term variability of aerosol optical thickness in Eastern Europe over 2001-2014 according to the measurements at the Moscow MSU MO AERONET site with additional cloud and $\mathrm{NO}_{2}$ correction. Atmos. Meas. Tech. 2016, 9, 313-334. [CrossRef]

7. Taschilin, M.A.; Mikhalev, A.V.; Kabanov, D.M. Variations of atmospheric aerosol optical depth in the Tunka valley during 2004-2017. In Proceedings of the 24th International Symposium on Atmospheric and Ocean Optics: Atmospheric Physics, Tomsk, Russia, 2-5 July 2018. [CrossRef]

8. Plakhina, I.N.; Makhotkina, E.L.; Pankratova, N.V. Variations in the atmospheric aerosol optical depth from the data obtained at the Russian actinometric network in 1976-2006. Izvestiya Atmos. Ocean. Phys. 2009, 45, 456-466. [CrossRef]

9. Remer, L.A.; Kaufman, Y.J.; Tanre, D.; Mattoo, D.; Chu, D.A.; Martins, J.V.; Li, R.R.; Ichoku, C.; Levy, R.C.; Kleidman, R.G.; et al. The MODIS aerosol algorithm, products and validation. J. Atmos. Sci. 2005, 62, 947-973. [CrossRef]

10. Mehta, M.; Sharma, V.; Doley, G.J. Aerosol optical depth variation during a recent dust event in north India. Environ. Pollut. 2018, 77, 567-571. [CrossRef]

11. Li, Y.; Shi, G.P.; Sun, Z. Evaluation and improvement of MODIS aerosol optical depth products over China. Atmos. Environ. 2020, 223, 117251. [CrossRef]

12. Ali, G.; Bao, Y.S.; Boiyo, R.; Tang, W.Y.; Lu, Q.F.; Min, J.Z. Evaluating MODIS and MISR aerosol optical depth retrievals over environmentally distinct sites in Pakistan. J. Atmos. Sol. Terr. Phys. 2019, 183, 19-35. [CrossRef] 
13. Mishra, A.K.; Lehahn, Y.; Rudich, Y.; Koren, I. Co-variability of smoke and fire in the Amazon basin. Atmos. Environ. 2015, 109, 97-104. [CrossRef]

14. Bryson, R.A.; Goodman, B.M. Volcanic activity and climatic changes. Science 1980, 207, 1041-1044. [CrossRef] [PubMed]

15. Kabanov, D.M.; Sakerin, S.M. Variations of the characteristics of the aerosol optical depth under conditions of forest fires. In Proceedings of the SPIE, 13th Joint International Symposium on Atmospheric and Ocean Optics/Atmospheric Physics, Tomsk, Russia, 2-7 July 2006; Matvienko, G.G., Ed.; SPIE: Bellingham, WA, USA, 2006; Volume 6522. [CrossRef]

16. Chubarova, N.; Nezval', Y.; Sviridenkov, M.; Smirnov, A.; Slutsker, I. Smoke aerosol and its radiative effects during extreme fire event over Central Russia in summer 2010. Atmos. Meas. Tech. 2012, 5, 557-568. [CrossRef]

17. Sitnov, S.A.; Gorchakov, G.I.; Sviridenkov, M.A.; Gorchakova, I.A.; Karpov, A.V.; Kolesnikova, A.B. Aerospace monitoring of smoke aerosol over the European part of Russia in the period of massive forest and peatbog fires in July-August of 2010. Atmos. Ocean. Opt. 2013, 26, 265-280. [CrossRef]

18. Zhuravleva, T.; Kabanov, D.; Nasrtdinov, I.; Russkova, T.; Sakerin, S.; Smirnov, A.; Holben, B. Radiative characteristics of aerosol under smoke mist conditions in Siberia during summer 2012. Atmos. Meas. Tech. 2017, 10, 179-198. [CrossRef]

19. Kinne, S.; Lohmann, U.; Feichter, J.; Schulz, M.; Timmreck, C.; Ghan, S.; Easter, R.; Chin, M.; Ginoux, P.; Takemura, T.; et al. Monthly averages of aerosol properties: A global comparison among models satellite data and AERONET ground data. J. Geophys. Res. 2003, 108. [CrossRef]

20. Panchenko, M.V.; Kozlov, V.S.; Polkin, V.V.; Terpugova, S.A.; Polkin, V.V.; Uzhegov, V.N.; Chernov, D.G.; Shmargunov, V.P.; Yausheva, E.P.; Zenkova, P.N. Aerosol characteristics in the near-ground layer of the atmosphere of the city of Tomsk in different types of aerosol weather. Atmosphere 2020, 1, 20. [CrossRef]

21. Gorbarenko, E.V.; Rublev, A.N. Long-term changes in the aerosol optical thickness in Moscow and correction under strong atmospheric turbidity. Izvestiya Atmos. Ocean. Phys. 2016, 52, 188-195. [CrossRef]

22. Latysheva, I.V.; Vologzhina, S.Z.; Barkhatova, O.A.; Loshchenko, C.A.; Sutyrina, E.N. Circulation factors in climate change in the Baikal region. In Proceedings of the SPIE, 25th International Symposium On Atmospheric and Ocean Optics-Atmospheric Physics, Novosibirsk, Russia, 30 June-5 July 2019; Matvienko, G.G., Romanovskii, O.A., Eds.; SPIE: Bellingham, WA, USA, 2019; Volume 11208. № 112086L. [CrossRef]

23. Zhamsueva, G.; Zayakhanov, A.; Tcydypov, V.; Dementeva, A.; Balzhanov, T. Spatial-temporal variability of small gas impurities over lake Baikal during the forest fires in the summer of 2019. Atmosphere 2021, 12, 20. [CrossRef] 